マルチセル構造を有する天然繊維の引張負荷による回転現象

ーケナフ繊維による確認実験と理論考察—

\author{
合田 公一 ${ }^{* 1, \#}$ ・新田 悠二*2
}

\title{
Rotation of a Multi-Cell Structure Natural Fiber during Tensile Loading -Experimental Validation and Theoretical Consideration by Using a Kenaf Fiber-
}

\author{
Koichi Goda ${ }^{* 1, \#}$ and Yuji Nitta ${ }^{* 2}$ \\ ${ }^{* 1}$ Department of Mechanical Engineering, Yamaguchi University, 2-16-1, Tokiwadai, Ube, \\ Yamaguchi, 755-8611 Japan \\ ${ }^{* 2}$ Graduate School of Science and Engineering, Yamaguchi University, 2-16-1, Tokiwadai, Ube, \\ Yamaguchi, 755-8611 Japan
}

\begin{abstract}
The purpose of this study is to confirm a rotation phenomenon around the fiber axis of a kenaf fiber, a representative multi-cell type fiber, during tensile loading, and clarify the rotation mechanism through 3D finite element analysis. The degree of rotation was quantified by measuring rotation angle during the tensile test of a single fiber, by giving a free mechanical condition perpendicular to the tensile direction. Results showed that, although many fiber specimens did not rotate during tensile loading, the rotation was confirmed for approximately one fourth of all the specimens. Young's moduli of the rotation identified specimens are almost the same level as non-rotating fibers, while these fibers indicated a slight decrease in strength, as compared with non-rotating fibers. The coordinates transformation matrix simulating a spatial spiral structure of cellulose microfibrils (CMF) was constructed, and applied for 3D finite element analysis. The calculation results show that rotation occurs in one-cell and seven-cell finite element models, but the magnitude of rotation is much smaller in the seven-cell model. Furthermore, a cell twisted finite element model was carried out to simulate a small-scale disorder in the multi-cell orientation structure, which was observed on the kenaf fiber surface. Finally, it is estimated from the calculation results that rotation occurs only for the fiber in which the mechanical balance between CMF spiral structure and multi-cells' intertwist is not enough.
\end{abstract}

(Received 18 June, 2014 ; Accepted 31 July, 2014)

\section{1. 緒 言}

昨今, 環境負荷低減の観点から, 带麻, 大麻, ジュー ト，ケナフなどの植物系天然繊維が複合材料の強化材と して多々用いられるようになった。このような複合材料 は, 一方向単層板や射出成形品として幅広い実用化が期 待されている。一般に, 植物系天然瀻維は単繊維ではな く, 多くの素纎維細胞(以下，七ルと略記する)が集まっ て構成された繊維束状構造体である。 セル内にはセルロー スミクロフィブリル (Cellulose microfibrils，以下 CMF と略 記する) と呼ばれるセルロースの集合体がセルの軸周にら せん状に配向する. CMFのらせん配向角度(以下, CMF 角と略記する)は，天然纎維の強度・剛性を左右する重要

\# corresponding author

*1 山口大学 機械工学科

*2 山口大学大学院 理工学研究科
なパラメータであり，実験的解析的に CMF 角の役割が明 らかにされている。このような生体由来内部構造と機械 的性質の関係について, 従来はセル 1 本から成る天然瀻 維(以下，シングルセル瀻維と記す）に基づいて論じられ てきたが $[1,2]$, 最近では上述の多数のセルから成る天然 瀻維(以下，マルチセル瀻維と記す)を対象とした議論も 展開されている $[3,4]$.

ところで, 植物系天然緘維固有の現象として, 吸水等 による膨潤時に繊維の回転が確認されている[2,5,6]。こ れは, CMF のらせん状配向がゆえに生じるものであり， 引張りによる力学的負荷によっても回転することが示唆 されている $[2,4]$. しかしながら, このような現象の機構 はシングルセル瀻維に基づいて考察されたものであり, マルチセル瀻維に対する機構については触れられていな い. Fig. 1 に天然瀻維の回転現象に係わる概念図を示す. 上述の CMF がらせん状に配置する部位は， $\mathrm{S}_{2}$ 細胞壁と呼 ばれている.この細胞壁には $\mathrm{S}_{1}$ および $\mathrm{S}_{3}$ と呼ばれる $\mathrm{CMF}$ 
Table 1 Properties of kenaf fibers $[9,10]$

\begin{tabular}{cccccc}
\hline $\begin{array}{c}\text { Cellulose } \\
(\mathrm{wt} \%)\end{array}$ & $\begin{array}{c}\text { Hemicellulose } \\
(\mathrm{wt} \%)\end{array}$ & $\begin{array}{c}\text { Lignin } \\
(\mathrm{wt} \%)\end{array}$ & $\begin{array}{c}\text { Pectin } \\
(\mathrm{wt} \%)\end{array}$ & $\begin{array}{c}\text { Density } \\
\left(\mathrm{g} / \mathrm{cm}^{3}\right)\end{array}$ & $\begin{array}{c}\text { CMF angle } \\
(\mathrm{deg})\end{array}$ \\
\hline $45-57$ & 21.5 & $8-13$ & $3-5$ & 1.4 & 10 \\
\hline
\end{tabular}

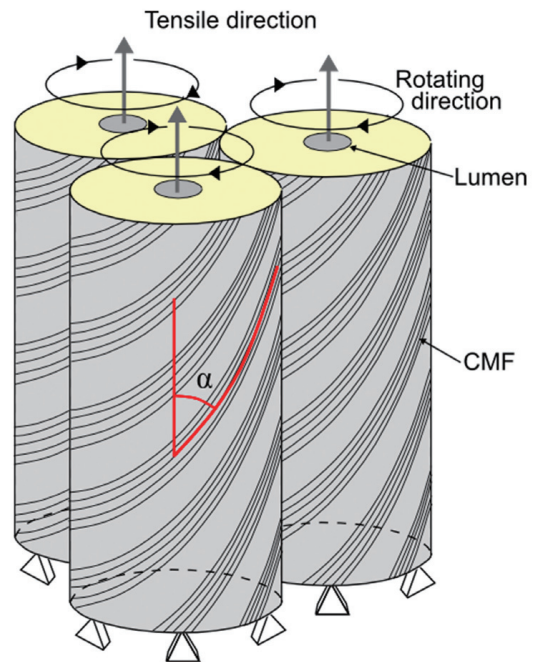

Fig. 1 Concept of multi-cell structure and rotation during tensile loading of a natural fiber. (In this figures, only the secondary walls $\mathrm{S}_{2}$ are drawn schematically to easily understand the relation between the rotation and cellulose microfibrils (CMF) orientation. $\alpha$ : CMF angle)

角の大きな細部壁も接しているが, $\mathrm{S}_{2}$ 細胞壁の $\mathrm{CMF}$ 角が $20^{\circ}$ 以下程度と比較的小さいため, この部位が天然繊維の 力学的性質を支配すると言われている $[1,4]$. Fig. 1 では簡 単のため, この部分のみを表示している. Fig. 1 の個々の シングルセルに着目すると，回転矢印で示すように，引 張負荷の作用によって回転が生じることは容易に推測で きよう。これに対しマルチセル繊維では，セル同士が膠 着している部分において CMF がクロスして配置されてい るので, 回転が起こらないか, または回転したとしても わずかであると予想される。このようなマルチセル繊維 の回転挙動やそのモデリングに関する報告は, 著者らの 知る限り，皆無である.

そこで, 本研究では代表的なマルチセル繊維であるケ ナフを用い, まず引張負荷時に繊維の回転が生じ得るか どうかを確認するとともに，回転が生じる場合と生じな い場合の力学的性質のちがいについて調査した．続いて CMF を空間内でらせん状に配置できるようにモデル化す るとともに, これを有限要素解析に組み込み, 回転機構 の定性的解明を試みたので報告する.

\section{2. 実験方法}

\section{1 供試材料}

実験に用いた天然繊維は, 代表的なマルチセル繊維で あるケナフ(Hibiscus cannabinus, ベトナム産)である.こ

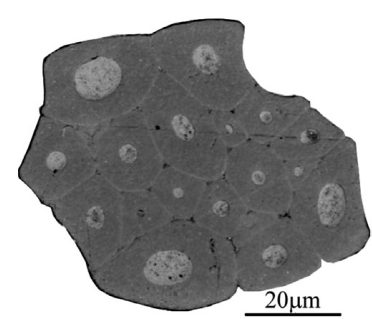

Fig. 2 Typical cross-section of a kenaf fiber.

の繊維は，環境に優しい資源として紙や薄板用素材，あ るいは PLA 系複合材料の強化材としてしばしば用いられ ている $[7,8]$. ケナフ繊維の特性および横断面写真を Table 1 およびFig. 2 にそれぞれ示す. Fig. 2 から, 用いた ケナフは明らかにマルチセル構造を呈することがわかる.

\section{2 引張試験および回転角の導出}

ケナフ単繊維の引張試験は, JIS 規格「炭素繊維 - 単繊 維の引張特性の試験方法(JIS7606)」に準じ, 引張圧縮試 験機 (山口大学製, 容量 : 19.6N) を用いて実施した. 張試 験片のゲージ長さは $25 \mathrm{~mm}$, 引張速度は $1.0 \mathrm{~mm} / \mathrm{min}$ であ る. 試験片の投影幅はレーザスキャンマイクロメータ (LSM-500S, Mitutoyo Co.) を用い, 繊維の軸方向に沿って $0.1 \mathrm{~mm}$ 間隔で $0^{\circ}, 60^{\circ}$, および $120^{\circ}$ の 3 方向から測定する とともに, 繊維断面積を DBA(Data-Based Approximation) 法 $[11,12]$ より推定した. ここでは, 文献 $[11]$ と同様に断 面形状を六角形と仮定した。 その結果, 今回測定した断 面積の平均值は $3438 \mu \mathrm{m}^{2}$, 変動係数は 0.208 であった。 な お, 試験本数については, 統計処理におけるばらつきの 収束性として試料数 40 以上が推奨されており [13], 本研 究でもこれに準じた.

繊維の回転現象を観察するにあたり, 試験機の掴み治 具の上部は金属製丸棒で支え, 金属リングを介した連結 構造とした。この機構により, リングは $180^{\circ}$ 未満の角度 範囲で回転することができる.

繊維回転角はデジタルマイクロスコープ(KH-1300, HiROX)によって引張試験中に撮影された動画像から測定 した. 最初の画像で, 特徵点を初期点に設定し, この点 が破断するまで連続的に存在するかを確認した．特徵点 が最後の画像まで存在するとき, 回転角 $\psi$ と画像上での 移動距離 $L$ の関係は Fig. 3 に示すようになる. $L$ は

$$
L=x_{0}-x_{0} \cos \psi+y_{0} \sin \psi
$$

であり， $x_{0}$ と $y_{0}$ は X-Y 平面上の原点 $(0,0)$ から設定された 初期特徴点の位置座標である. 実験では, $L$ を初期画像 からの最終画像の移動距離とした. 本研究では, 原点を 


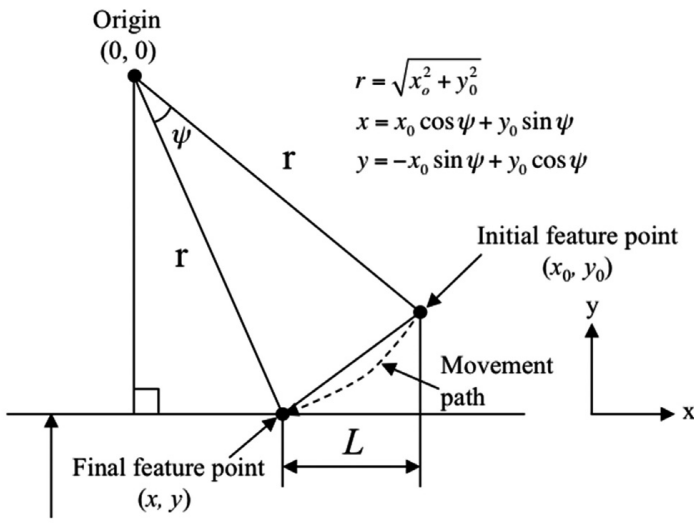

Observing direction

Fig. 3 Schematic of movement path from initial feature point $\left(x_{0}, y_{0}\right)$ to final feature point $(x, y)$, and measured distance $L$.

DBA から導出した仮定 6 角形の 3 本の対角線の交点とし て認識し， $y_{0}$ は 6 角形の辺上の点として仮定した．以上 より, 回転角 $\psi$ は式 (1)を陰解法で解くことによって得ら れる。

\section{3. 実験結果}

Fig. 4 に引張試験中の瀻維表面写真を示す．矢印で示す ように，特徵点(突起物) は上側に移動するだけでなく, 徐々に左 (Fig. 4 (a)) から右 (Fig. 4 (c))へ移動していくこ とがわかる。このとき, 突起物が手前に移動し，その形 状が見えにくくなったことから回転していると判断でき る.すなわち, 本研究においてマルチセル瀻維の引張負 荷による回転現象が確認された，以下，このような回転 を反時計回りと称す．Fig. 4 では回転とともに，緎維の幅 も変化することが観察される。.これは，Fig. 2 に一例を示 すように，ケナフ瀻維の断面が複雑な形状をしており， 回転によって繊維幅が変わりながら観察されるためであ る。一方，この例とは逆に時計回りに回転する試験片も いくつか確認できたが, 多くの瀻維において回転を確認 することはできなかった，Table 2 に試験片の引張試験結 果を示す．回転が確認された試験片は 11 本であった，以 後, 回転が確認された試験片をRI-試験片 (Rotationidentified specimen), 回転を確認できなかったものを NRI試験片 (Non-rotation-identified specimen) とそれぞれ略記す る. RI-試験片のうち, 時計回りのものは 5 本, 反時計周 りは 6 本であった。つまり，RI-試験片は全体の約 $1 / 4$ を 占め, 引張負荷によって回転が生じる確率は $1 / 4$ 程度であ る。また，すべての試験片の結果と比較すると，引張強 度はやや低くなることがわかる。一方，ヤング率につい てはほぼ同程度の值を示した．回転現象がマルチセル瀻 維の内部構造に起因するならば，他の構造材料と同じく， 植物系天然繊維もまたその強度は構造に敏感であり，剛 性は構造に鈍感な特性であると思われる．Fig. 5 に測定し た回転角と引張強度抢よびヤング率との関係を示す。引
Table 2 Tensile properties of kenaf fiber specimens

\begin{tabular}{cccc}
\hline & $\begin{array}{c}\text { Corresponding } \\
\text { number }\end{array}$ & $\begin{array}{c}\text { Tensile } \\
\text { strength } \\
(\mathrm{MPa})\end{array}$ & $\begin{array}{c}\text { Young's } \\
\text { modulus } \\
(\mathrm{GPa})\end{array}$ \\
\hline Total & 42 & 350 & 33.0 \\
RI & 11 & $(0.331)$ & $(0.303)$ \\
specimens & & 331 & 32.8 \\
NRI & 31 & 357 & $(0.330)$ \\
specimens & 31.1 & $(0.347)$ & $(0.293)$ \\
\hline
\end{tabular}

The values in parentheses are coefficients of variation.

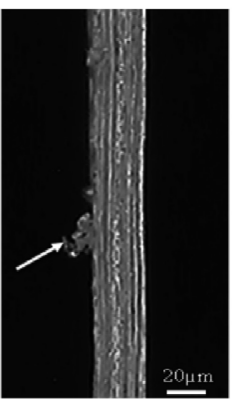

(a)

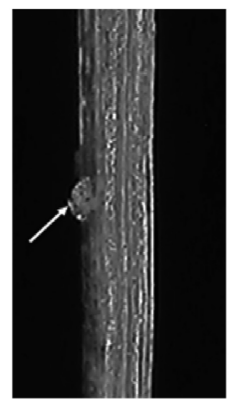

(b)

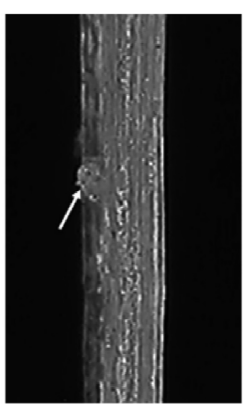

(c)
Fig. 4 Observation of rotation during tensile test of a kena fiber.

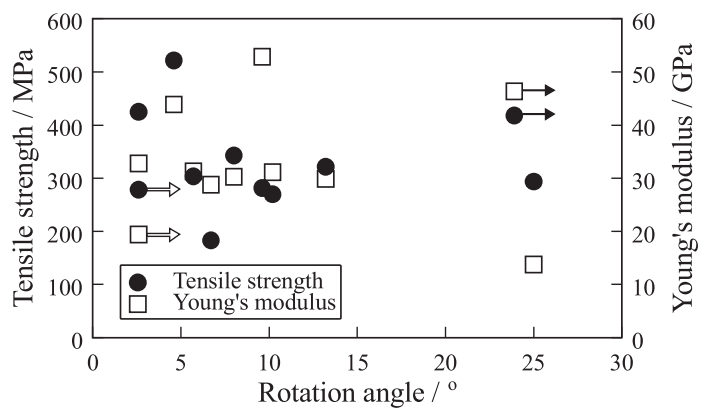

Fig. 5 Effect of rotation angle on tensile strength and Young's modulus. Rotation angles of two specimens were not measured in the total number of RI-specimens, because the feature points moved to the outside of observation image (black arrows) or became defocus (white arrows) during tensile test.

張強度は回転角と相関があるように見えるが，相関係数 はわずか -0.211 と算出された，すなわち, 瀻維強度の回 転角への依存性は小さいと思われる。一方，ヤング率と 回転角の関係について相関倸数を求めたところ -0.518 と 算出された。この值は両者の間に少なからず相関関係を 認めるものである。しかしながら，本研究で見積もった 上述の係数值は, RI-試験片のうち回転が計測できなかっ た2つを除外しており，わずか 9個のデー夕による推定 值であることから十分に信頼性のある值とは言えない. RI試験片の回転角と強度・剛性の関係については, 今後の 課題としてさらなる検討を要する。

以上の回転の機構は，CMF のらせん状配向が主要因で あると考えられる，すなわち，文献[14,15]でも指摘され ているように，天然瀻維のセル内の CMF の多くは‘Z’型 


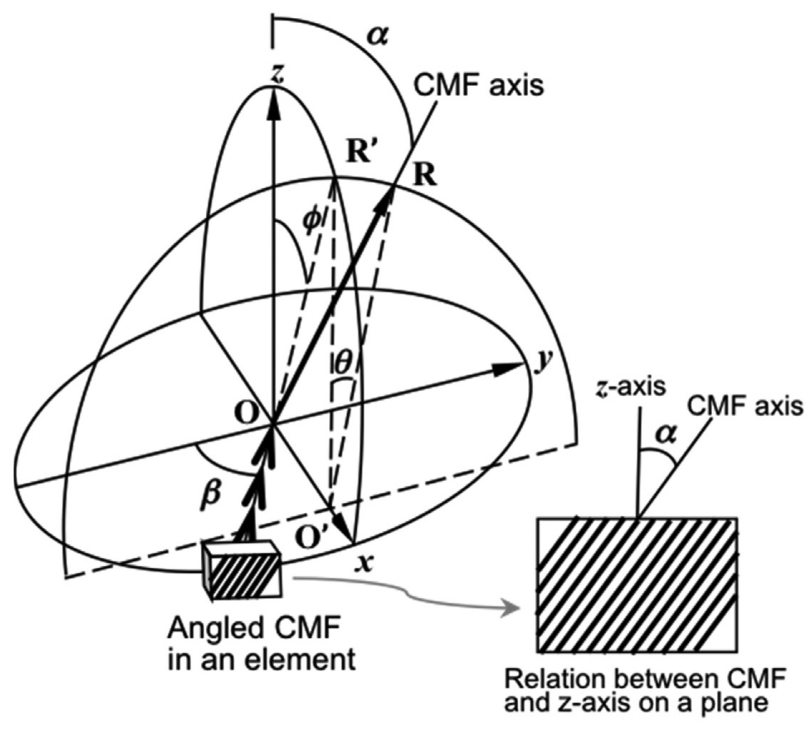

Fig. 6 Schematic of coordinates transformation on $x-z$ and $y-z$ planes.

のらせん配置(以下, Z-helix と記し, 'S'型のらせん配置 を S-helix と記す)を取っている. このため, 引張負荷に より CMF 角が減少し，これにともなって回転が生じると 考えられる。しかし，マルチセル繊維では，七ルが互い にリグニン等の細胞間物質で膠着されているので, 緒言 でも述べたように，相対するセル間において CMF 角はク ロスし，回転を妨げる，そこで，本研究では以上のよう なマルチセル繊維の回転機構を, 力学モデルを通して検 証する.

\section{4. 考 察}

\section{1 解析方法}

マルチセル瀻維の回転現象のモデリングにあたり，そ の構造を以下のように仮定する.

(1) 各セルを巨視的には直交異方性体で表現できるも のとし，連続体として扱う。

(2) $\mathrm{CMF}$ は, $10^{\circ}$ 程度の小傾角を有しながら, セルの 中心軸周りにらせん状に一様に配置される。

(3) 七ル間のリグニン等の存在を除外できるものとする. セル内の CMF は, 結晶秩序が分子鎖方向に寸断された準 周期的不均質構造を呈するものの [16], 巨視的な力学挙 動を論ずる場合，へミセルロースを含んだ直交異方性連 続体としてしばしば扱われる[4,18-20]. (1)はその仮定で ある.CMFはセルの表層において無秩序に配列され，ま た内部の一部においても比較的大きく傾いて配置される [19]が, 本研究では体積の多くを占め, また荷重の大半 を担う $\mathrm{S}_{2}$ 細胞壁の挙動に着目した。(2)はその仮定である。 一方, 後述の有限要素分割に対してリグニンをセルの要 素間に配置することは可能である。しかしながら, リグ ニンは巨視的異方性を持ち合わせない要素であり, かつ 低弾性率要素なので $[1,4,21]$, これを導入せずとも回転機 構の定性的解明に支障はないと考えた。（3)はその仮定で
ある。

力学モデルとして，仮定(1)(2)゙述べたように， CMFの らせん構造を直交異方性体の応力ーひずみマトリックス の座標変換によって表現する。一般に, 直交異方性体の 応力ーひずみマトリックス $[\mathrm{D}]$ は,

$$
[\mathrm{D}]=\left[\begin{array}{cccccc}
\frac{1-v_{23} v_{32}}{E_{22} E_{33} \Delta} & \frac{v_{12}-v_{13} v_{32}}{E_{11} E_{33} \Delta} & \frac{v_{21}+v_{21} v_{32}}{E_{22} E_{33} \Delta} & 0 & 0 & 0 \\
\frac{v_{12}-v_{13} v_{32}}{E_{11} E_{33} \Delta} & \frac{1-v_{31} v_{13}}{E_{11} E_{33} \Delta} & \frac{v_{23}-v_{21} v_{13}}{E_{11} E_{22} \Delta} & 0 & 0 & 0 \\
\frac{v_{31}+v_{21} v_{32}}{E_{22} E_{33} \Delta} & \frac{v_{23}-v_{21} v_{13}}{E_{11} E_{22} \Delta} & \frac{1-v_{12} v_{21}}{E_{11} E_{22} \Delta} & 0 & 0 & 0 \\
0 & 0 & 0 & G_{23} & 0 & 0 \\
0 & 0 & 0 & 0 & G_{31} & 0 \\
0 & 0 & 0 & 0 & 0 & G_{12}
\end{array}\right]
$$

と表わされる.ここで, $E_{11}, E_{22}$ はそれぞれ主軸である $\mathrm{CMF}$ 軸(3-軸)に垂直方向のヤング率であり， $E_{33}$ は $\mathrm{CMF}$ 軸方 向のヤング率である. $v_{i j}(i, j=1,2,3)$ は, $i$ 軸方向に負荷 されたときの $j$ 軸方向の横ひずみに対するポアソン比で ある、 $G_{23} ， G_{31}, G_{12}$ はそれぞれ 2-3，3-1，1-2 面のせん断 弾性係数である。また，

$$
\Delta=\frac{1}{E_{11} E_{22} E_{33}}\left(1-v_{12} v_{21}-v_{23} v_{32}-v_{31} v_{13}-2 v_{12} v_{23} v_{31}\right)
$$

である。 また座標変換マトリックス $[\mathrm{T}]$ は

$$
\begin{aligned}
& {[\mathrm{T}]=\left[\begin{array}{cccccc}
l^{2} & m^{2} & n^{2} & 2 l m & 2 m n & 2 n l \\
l^{\prime 2} & m^{\prime 2} & n^{\prime 2} & 2 l^{\prime} m^{\prime} & 2 m^{\prime} n^{\prime} & 2 n^{\prime} l^{\prime} \\
l^{\prime \prime 2} & m^{\prime \prime 2} & n^{\prime \prime 2} & 2 l^{\prime \prime} m^{\prime \prime} & 2 m^{\prime \prime} n^{\prime \prime} & 2 n^{\prime \prime} l^{\prime \prime} \\
l^{\prime} & m m^{\prime} & n n^{\prime} & l m^{\prime}+l^{\prime} m & m n^{\prime}+m^{\prime} n & n l^{\prime}+n^{\prime} l \\
l^{\prime} l^{\prime \prime} & m^{\prime} m^{\prime \prime} & n^{\prime} n^{\prime \prime} & l^{\prime} m^{\prime \prime}+l^{\prime \prime} l m^{\prime} & m^{\prime} n^{\prime \prime}+m^{\prime \prime} n^{\prime} & n^{\prime} l^{\prime \prime}+n^{\prime \prime} l^{\prime} \\
l l^{\prime \prime} & m m^{\prime \prime} & n n^{\prime \prime} & l m^{\prime \prime}+l^{\prime \prime} m & m n^{\prime \prime}+m^{\prime \prime} n & n l^{\prime \prime}+n^{\prime \prime} l
\end{array}\right]} \\
& \begin{array}{lll}
l=\cos \phi & m=-\sin \phi \sin \theta & n=-\sin \phi \cos \theta \\
l^{\prime}=0 & m^{\prime}=\cos \theta & n^{\prime}=-\sin \theta
\end{array} \\
& \begin{array}{lll}
l^{\prime \prime}=\sin \phi & m^{\prime \prime}=\cos \phi \sin \theta & n^{\prime \prime}=\cos \phi \cos \theta
\end{array}
\end{aligned}
$$

と表わされる。 ここで， $\phi$ と $\theta$ は 3 次元直交座標系にお いて，それぞれ主軸(ベクトル OR 上の軸)の $x-z$ 平面およ び $y-z$ 平面上に扔ける $z$ 軸执よびベクトル O'R'からの傾 角である．Fig. 6 にその座標系と主軸が傾いた様相を示す， このとき, 角度 $\alpha$ は式(3)の $n$ "”にあたる $\cos \phi \cos \theta$ の逆関 数で与えられる. $\alpha$ を満たす $\phi$ と $\theta$ の組み合わせは無数 にあるので，これを仮定(2)で述べたように，七ルの周軸 に一様に配置させるために $x-y$ 平面上における $y$ 軸からの 周方向になす角度 $\beta$ を導入した。

Fig. 6 に, CMF を有する 6 面体要素が角度 $\beta$ ほど旋回 して Z-helix 状に配置される例を追示している. CMF 角 $\alpha$ と $\mathrm{CMF}$ 軸は, 原点 $\mathrm{O}$ から $x-y$ 平面内で半径方向に伸びた 法線に対する垂直面 (Fig. 6 の CMF を有する 6 面体要素上 の面)では常に一定に与えられる。これを Fig. 6 内の矢印 で示すように，原点 $\mathrm{O}$ に向けて移動させるとき, $\mathrm{CMF}$ 軸 はべクトル OR と一致し，また CMF 角は先述の $\cos \phi \cos \theta$ の逆関数で与えられ，それぞれ 3 次元表示となる。 これ を $z$ 軸周りでらせん状に一様に表現するために, $\beta$ を各要 素の座標に応じて割り振ることで $\phi$ と $\theta$ を見積もった. その換算式を Table 3 に整理して示す. $\alpha$ と $\beta$ を適宜与え ることにより $\phi$ が算出でき，これを用いて $\theta$ を見積もる ことができる，各值は第 1 象限から第 4 象限にかけて異 


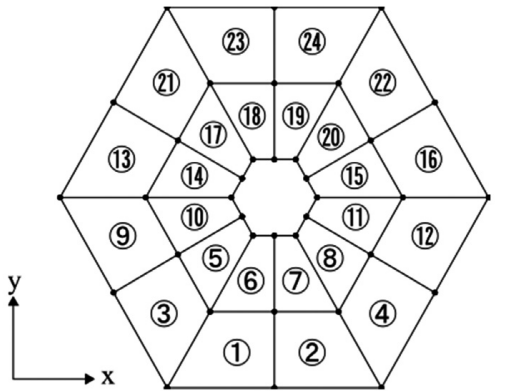

(a)

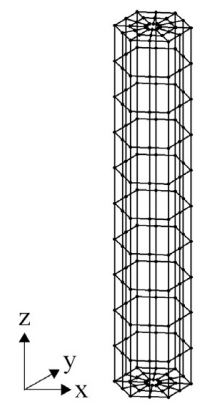

(b)
Fig. 7 FEM mesh of one elementary cell. (a) Crosssectional FE mesh, (b) 3D-FE mesh

なった換算式になるものの, これを各要素の座標に応じ て配置することにより，らせん構造の空間的表現が可能 となる.らせん構造の応力ーひずみ関係式は, $[\mathrm{T}]^{-1}[\mathrm{D}][\mathrm{T}]$ によって表わされるが, マルチセル繊維の回転機構をよ り詳しく調査するために, 本研究ではこれを 3 次元有限 要素解析に導入した，有限要素分割として，まず Fig. 7 に 示すような縦方向にセル層を直線状に積上げたマルチセ ル纎維モデルを作成した，使用した有限要素は，後述の セルのねじれ構造を考慮し，アイソパラメトリック 8 節 点 6 面体要素とした。 また，要素分割は Fig. 7 (a)に示す ように，1つのセルモデルの断面は中央にルーメンを有す る六角形と仮定し, Fig. 7 (b)のように単一七ルを積上げ た(以下, 1-cell モデルと記す). また, セルの 1 辺の長さ はケナフ繊維の断面観察から $0.005 \mathrm{~mm}$ とし, 軸方向の高 さは $0.02 \mathrm{~mm}$ とした.

本研究では, 文献 $[14,15]$ から CMF のらせん構造を Zhelix に仮定して計算を実施した．また，上述の周方向角 度 $\beta$ については，以下のように割り振った。 (1)(2)(6)(18) (19)(23)に対して $\beta=0^{\circ}$ とし, その他の要素には $\beta=60^{\circ}$ を 代入した．各要素が位置する象限の換算式に所定の $\alpha$ お よび $\beta=0^{\circ}$ または $60^{\circ}$ を代入することにより, 座標変換 マトリックスに用いる $\phi$ および $\theta$ を得た，本計算で用い た弾性定数の值を以下に示す.

$E_{11}=E_{22}=10.0 \mathrm{GPa}, \quad E_{33}=30.0 \mathrm{GPa}, \quad G_{12}=G_{23}=G_{31}=7.0 \mathrm{GPa}$, $v_{31}=v_{32}=0.2, \quad v_{12}=0.3$

$E_{33}$ は文献[11]で得られた実験結果を参考にして決定した $E_{11}, E_{22}$ は文献 $[3,18,19]$ から $E_{3}$ のおおよそ $1 / 3$ 程度であっ たことから $10.0 \mathrm{GPa}$ とした. せん断弾性係数については, 一方向繊維強化材については $E_{11}, E_{22}$ のおおよそ $0.5 \sim 0.8$ 倍の值を取ることが多く, 本研究では簡単のため, すべ て 0.7 倍の值として統一した. ポアソン比についてはセル ロース等の軸方向のポアソン比が 0.2 程度であるため, $v_{31}$ を 0.2 とした[1]. また， $v_{12}$ については著者らが調べた範

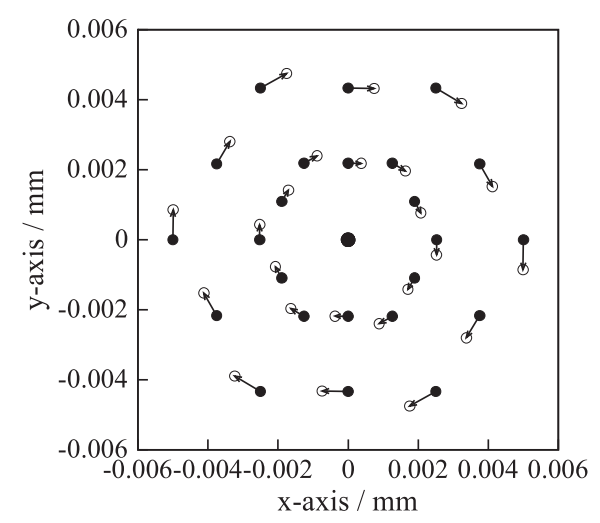

Fig. 8 Nodal-points (•) before and ( $($ ) after calculation displacement vectors of one-cell model at $\alpha=10^{\circ}$ (Top view)

囲内において出典が見当たらず，便宜上 0.3 とおいた，境 界条件として, 要素底面の節点の $z$ 軸方向を固定条件と し, 上面の各節点に対して $z$ 方向に強制変位 $0.002 \mathrm{~mm}$ (ひ ずみ $1.0 \%$ に相当)を与えた。 また，底面のルーメンに当 たる節点についても $x$ および $y$ 方向に対して固定し, 上 面節点の $x$ および $y$ 方向はすべて拘束を外した。 なお, 本研究で用いた有限要素コードは著者らで作成したもの である。

\section{2 解析結果}

Fig. 8 に1-cell モデルで得られた上面節点の変位べクト ルを示す. 文献 $[10]$ を参考に, Fig. 8 は便宜上, $\alpha=10^{\circ}$ で 設定した結果であり，すべての節点は時計回りに回転す ることが確認できる. Z-helix は, 上から見ると反時計回 りのらせん構造であるが, 負荷を与えることによりその 逆回りの回転が生じる.このとき, 回転角は $0.2 \mathrm{~mm}$ の繊 維長あたり $4.89^{\circ}\left(24.5^{\circ} / \mathrm{mm}\right)$ であり, 繊維軸方向(非主軸 方向)のヤング率は $28.6 \mathrm{GPa}$ が得られた。一般に, 直交異 方性材料の非主軸方向におけるヤング率は以下のように 与えられる [17].

$$
E(\alpha)=\left\{\frac{\cos ^{4} \alpha}{E_{1}}+\left(\frac{1}{G_{12}}-\frac{2 v_{12}}{E_{1}}\right) \cos ^{2} \alpha \cdot \sin ^{2} \alpha+\frac{\sin ^{4} \alpha}{E_{2}}\right\}^{-1}
$$

ここで, $\alpha$ は非主軸角であり, 本研究の CMF 角に相当 する. 同じ弾性定数を用い, $\alpha=10^{\circ}$ を式(4)に代入する と, $28.5 \mathrm{GPa}$ が得られた. 1-cell モデルから得られる值と さほど変わらないものの, 式(4)によるヤング率は $0.1 \mathrm{GPa}$ ほど低くなる.マルチセル構造をシミュレートするため に, Fig. 9 に示すように, 有限要素分割を7-cell モデルに 拡張した. ここでは, 現象の定性的理解を目的とするた め, すべて 1-cell モデルと同じ大きさの六方配列としてい る. その結果, Fig. 10 に示すように, 1-cell モデル同様に 時計回りの回転が確認できた. 回転角度として $0.95^{\circ}$

Table 3 Relation of CMF and location angles $\alpha, \beta$ with coordinate transformation angles $\phi, \theta$

\begin{tabular}{ccccc}
\hline & First quadrant & Second quadrant & Third quadrant & Forth quadrant \\
\hline$\phi$ & $\tan ^{-1}(\tan \alpha \cdot \cos (\pi-\beta))$ & $\tan ^{-1}(\tan (\pi-\alpha) \cdot \cos (\pi+\beta))$ & $\tan ^{-1}(\tan (\pi-\alpha) \cdot \cos (-\beta))$ & $\tan ^{-1}(\tan \alpha \cdot \cos \beta)$ \\
$\theta$ & $\cos ^{-1}(\cos \alpha / \cos \phi)$ & $\cos ^{-1}(-\cos (\pi-\alpha) / \cos \phi)$ & $\cos ^{-1}(\cos (\pi-\alpha) / \cos \phi)$ & $\cos ^{-1}(-\cos \alpha / \cos \phi)$ \\
\hline
\end{tabular}




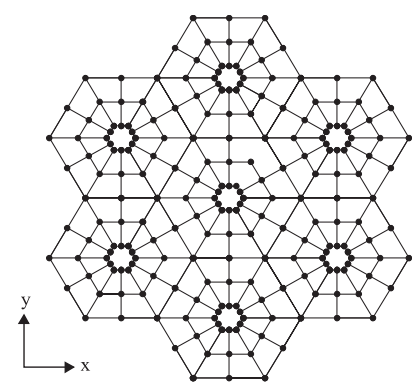

(a)

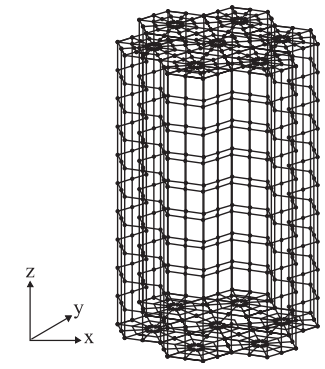

(b)
Fig. 9 FEM mesh of seven elementary cells. (a) Crosssectional FE mesh, (b) 3D-FE mesh.

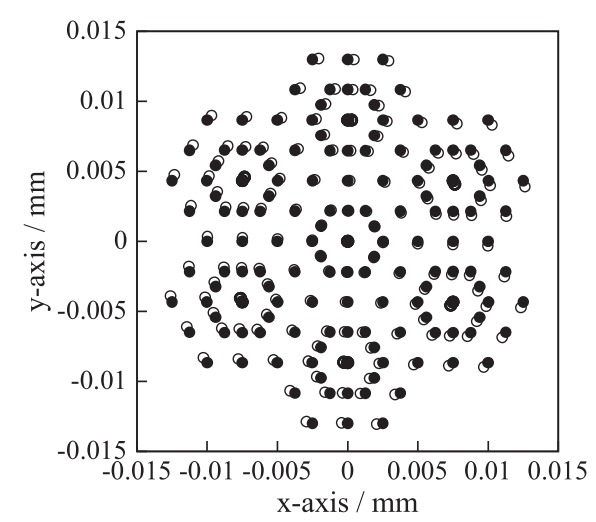

Fig. 10 Nodal-points position $(\bullet)$ before and $(\odot)$ after calculation of seven-cell model at $\alpha=10^{\circ}$ (Top view)



Fig. 11 Young's moduli of one-, two- and seven-cells obtained in the present FE model.

$\left(4.75^{\circ} / \mathrm{mm}\right)$ が得られ, 回転はするものの1-cell モデルよ り規模が小さくなる。これは，七ルとセルが接している 要素間では，上述のように CMF 角がクロスして配置され ており，回転が生じにくくなったことが原因と考えられ る. 得られたヤング率は29.1GPaであり，1-cell モデルよ り大きな值を示した．CMF角の変化にともなうヤング率 の推移を Fig. 11 に示す. 比較のため, 2-cell モデルの場 合も結果に加えた。これから，ヤング率は直交異方性材 料に拐けるよりもすべて大きく, 特に CMF 角が $10^{\circ}$ を過 ぎた辺りからその傾向が影著になる．また，七ル数が多 くなるにつれて, より高いヤング率を示すようになり， 纎維の回転を小さくするマルチセル構造は, ヤング率を 増加させる効果を有する.

これまでの計算結果から実際の回転機構を推測すると, シングルセルの回転が CMF のらせん構造によって生じる

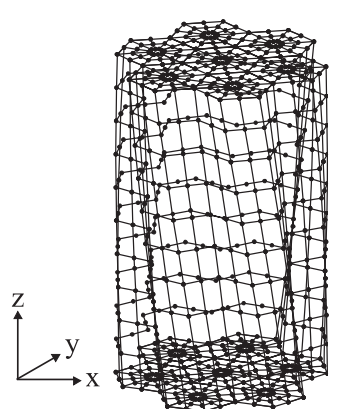

(a)

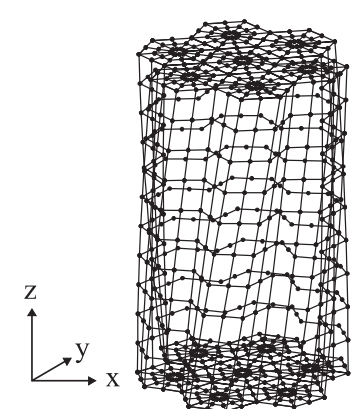

(b)
Fig. 12 3D-FE mesh with torsional cells. (a) Clockwise torsion, (b) Anticlockwise torsion.

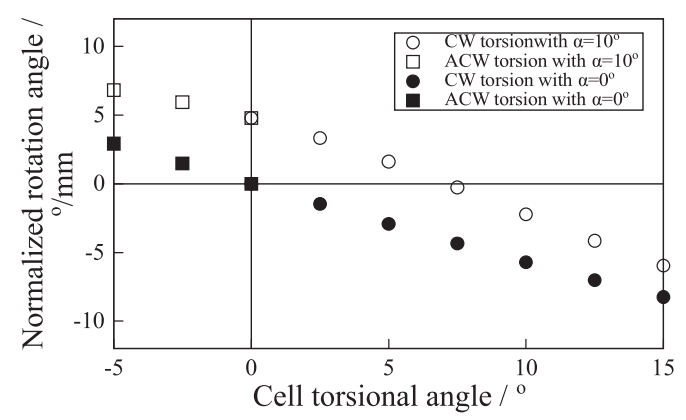

Fig. 13 Effect of cell torsional angle on rotation angle during tensile loading by $3 \mathrm{D}-\mathrm{FE}$ analysis. (CW : Clockwise, ACW : Anticlockwise)

限り, セルが多数隣り合ったケナフを始めとするマルチ セル繊維もまた CMF のらせん構造に起因して回転が発生 すると考えられる，そして力学的性質に関しても，同じ 繊維素材をシングルセルとして扱う場合に比ベ, ヤング 率はより大きく発現されると推測される。

ところで，第3章において NRI-試験片はRI-試験片よ り数多く存在した. 引張負荷による回転が CMF のらせん 状配置に依存するならば, CMF 角が極端に小さくない限 り, 回転はどの試験片でも生じるはずである。 そこでこ の矛盾点を解くために, 本研究ではセルの繊維方向の絡 み合いに着目した．Fig. 4 に示すように，七ル間の境界を 示す縦方向のしわは, ほぼ直線的に伸びている. しかし ながら, 各試験片を注意深く観察すると, しわはその配 向の傾きに微小ながら変動をともなって配置されている ことがわかった，セルは成長する過程で隣り合うセル同 士が密に凝集し，互いに絡まり合って伸びていくと考え られる. そこで, Fig. 9 の直線状に積み上げたセル構造を 改良し，絡み合いを有する有限要素分割を別途作成した。 ここでは簡単のため, 絡み合い構造をセルの積み上げの 段階で時計回りまたは反時計回りのねじれ構造に単純化 した、㸚じれ構造を有する有限要素分割を Fig. 12 に示す. このとき, Table 3 の換算式についてはセルのねじれ構造 によるモデルの傾きを考慮した，すなわち，本研究では， 中心のセルを除く6つのセルそれぞれの各層における重 心座標に応じて各象限ごとに角度 $\phi, \theta$ を考慮し Table 3 の換算式に加算した. 


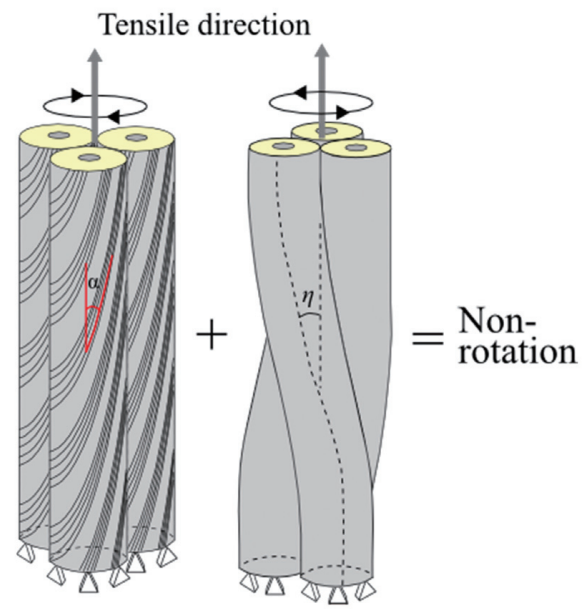

Fig. 14 Schematic of the non-rotating mechanism of a multi-cell type fiber. ( $\alpha$ and $\eta$ are CMF angle and cell torsional angle, respectively.)

Fig. 13 に計算結果を示す. 計算ではセルのねじれ角を $-5^{\circ} \sim 15^{\circ}$ の小規模な範囲に留め, CMF 角 $\alpha$ は $0^{\circ}$ または $10^{\circ}$ とした(ねじれ角は時計回りを正とする)。図中，○お よび $\square$ 印は $\alpha=10^{\circ}$ の結果を示す.これから, 回転角はセ ルのねじれ角の増加とともに減少することがわかる，そ の度合いは，例えばねじれ角 $7^{\circ} \pm 2^{\circ}$ 辺りでは回転角度が $\pm 2 \% / \mathrm{mm}$ 程度となり, 回転の大きさとしては極めて小さ い範囲にあると考えられる。一方，一扮よび四印は $\alpha=0^{\circ}$ の場合の結果である。このときもねじれ角の増加ととも に回転角は減少する。すなわち, 七ルのねじれ構造のみ でも回転の発生を確認することができた。この結果は, マルチセル繊維の回転機構が CMF のらせん構造だけによ るものではないことを示唆する.

以上の計算結果を実際の現象に照らし合わせ，以下に マルチセル繊維の回転機構を総括する。 まず NRI-試験片 は, Fig. 14 に示す概念図のように, CMFのらせん構造 (Fig. 14 左図)とセルの絡み合い構造(Fig. 14 右図)におい て力学的均衡が保たれ，CMFによる回転をセルの逆向き 回転で抑制していると推測される。一方，七ルの絡み合 いは統計的に時計方向または反時計方向に規模の大きい 場合も幾らか存在し, $\mathrm{CMF}$ のらせん構造と力学的均衡が 保てなくなった場合，RI-試験片のようにどちらかの回転 として発現されたのではないかと推測される. そして, 均衡の保てないようなセルの絡み合い構造は, 強度に影 響する構造欠陥としても作用し, RI-試験片の引張強度を 低下させた原因に関わったのではないかと考えられる.

今後は，セル構造をより詳細に観察するとともに現実 に即した構造を把握した上で, マルチセル繊維の回転現 象の定量的解明に取り組む予定である.

\section{5. 結 言}

代表的なマルチセル繊維であるケナフを取り上げ，引 張負荷による纎維軸周りの回転現象について調查した.
また，CMF を空間内でらせん状に配置するための座標変 換マトリックスを考案するとともに，これを有限要素解 析に組み込み, マルチセル纎維の回転機構について考察 を行なった，得られた結論は以下のように要約される.

（1）ケナフ繊維が引張負荷によって瀻維軸周りに回転す ることを確認した，ただし，すべての瀻維で回転が 起こるとは限らず, 試験数全体の約 4 分の 1 程度の 割合であった：また，その回転方向は時計回りまた は反時計回りのどちらかであった。

（2）回転の確認された瀻維は，回転の確認できなかった 繊維の引張強度と比較し, 若干低いことが認められ た，一方，ヤング率については両者ともほぼ同程度 の值を示した。

（3）CMF のらせん構造を Z-helix と仮定し，シングルセル 瀻維㧍よびマルチセル纎維の有限要素解析を行なっ たところ，ともに時計回りの回転が確認できた．た だし，後者の回転の度合いは前者におけるより小さ い.

(4)さらに, マルチセルの絡み合い構造を時計回りまた は反時計回りの微小なねじれ構造と仮定し, 同様な 有限要素解析を実施したところ, 時計回りのねじれ 構造において回転が生じないセルのねじれ角の存在 を確認した。

（5）以上から, ケナフ纎維の引張負荷時に観察される回 転は, $\mathrm{CMF}$ のらせん構造とマルチセルの絡み合い構 造の力学的均衡が保たれない場合に生じる現象であ ると推測される.

\section{文 献}

1. L. Salmén, A. Ruvo, Journal of Wood and Fiber Science, 17(3), 336-350 (1985).

2. E. Markland and J. Varna, Plastics, Rubber and Composites, 38, 118-123 (2009).

3. A. Beakou and K. Charlet, International Journal of Adhesion \& Adhesives, 43, 54-59 (2013).

4. V. Placet, F. Trivaudey, O. Cisse, V. Gucheret-Retel, M. Lamine Boubakar, Composites: Part A, 43, 275-287 (2012).

5. Kh. M. Mannan and Z. Robbany, Polymer, 37(20), 46394641 (1996).

6. T. Okano and Y. Nishiyama, Cellulose communications, 2, 2-5 (1995).

7. K. Inoue, S. Serizawa, M. Yamashiro, M. Iji, Proceedings of 6th International IEEE Conference on Polymers and Adhesives in Microelectronics and Photonics, 73-76 (2007).

8. T. Oda and M. Yamato, SAE Technical Paper, 2004-010731 (2004).

9. H. M. Akil, M. F. Omar, A. A. M. Mazuki, S. Safiee, Z. A. M. Ishak, A. Abu Bakar, Materials and Design, 32, 4107- 
4121 (2011).

10. N. Reddy, Y. Yang, Journal of Agricultural and Food Chemistry, 55, 8570-8575 (2007).

11. Y. Nitta, K. Goda, J. Noda, and W.-I., Lee, Composites: Part A, 49, 132-138 (2013).

12. K. Tanabe, T. Matsuo, A. Gomes, K. Goda, J. Ohgi, Zairyo/ Journal of the Society of Materials Science, Japan, 57, 454-460 (2008).

13. M. Kawai and H. Abe, Reports Res. Lab. Asahi Glass Co., Ltd., 30, 111-120 (1980).

14. Jörg Müssing. "Industrial Applications of Natural Fibres Structure, Properties and Technical Applications", John Wiley and Sons, Ltd. (2012).
15. C. Sellén and P. Isaksson, Journal of Composite Materials, 48, 277-289 (2014).

16. Cellulose Society of Japan, "Serurosu no jiten (Dictionary of cellulose)", Asakura Publishing Co., Ltd., p.100 (2000).

17. T. Komori, Textile Research Journal, 71(10), 898-904 (2004).

18. C. Baley, Composites : Part A, 33, 939-948 (2002).

19. P. Xu and H. Liu, Wood Science and Technology, 38, 363374 (2004).

20. J. Gassan, A. Chate and A. K. Beldzki, Journal of Material Science, 36, 3715-3720 (2001).

21. A. Bregander and L. Salmén, Journal of Materials Science, 37, 151-156 (2002). 